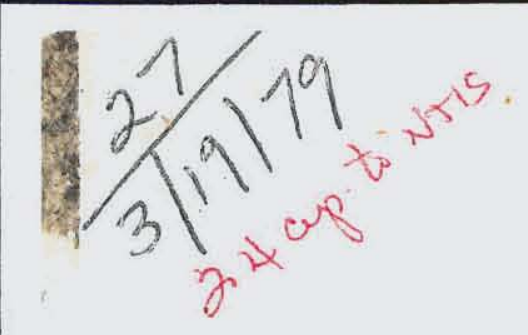

\title{
CASE HISTORY STUDY OF INTEGRATED UTILITIES AT LAWRENCE PARK HEAT, LIGHT AND POWER, BRONXVILLE, NEW YORK
}

\section{ARGONNE NATIONAL LABORATORY}

\section{ENERGY AND ENVIRONMENTAL SYSTEMS}

\section{INTEGRATED}

COMMUNITY

DIVISION

\section{"MASTER}




\section{DISCLAIMER}

This report was prepared as an account of work sponsored by an agency of the United States Government. Neither the United States Government nor any agency Thereof, nor any of their employees, makes any warranty, express or implied, or assumes any legal liability or responsibility for the accuracy, completeness, or usefulness of any information, apparatus, product, or process disclosed, or represents that its use would not infringe privately owned rights. Reference herein to any specific commercial product, process, or service by trade name, trademark, manufacturer, or otherwise does not necessarily constitute or imply its endorsement, recommendation, or favoring by the United States Government or any agency thereof. The views and opinions of authors expressed herein do not necessarily state or reflect those of the United States Government or any agency thereof. 


\section{DISCLAIMER}

Portions of this document may be illegible in electronic image products. Images are produced from the best available original document. 
The facilities of Argonne National Laboratory are owned by the United States Government. Under the terms of a contract (W-31-109-Eng-38) between the U.S. Department of Energy, Argonne Universities Association and The University of Chicago, the University employs the staff and operates the Laboratory in accordance with policies and programs formulated, approved and reviewed by the Association.

\section{MEMBERS OF ARGONNE UNIVERSITIES ASSOCIATION}

The University of Arizona Carnegie-Mellon University Case Western Reserve University The University of Chicago University of Cincinnati Illinois Institute of Technology University of Illinois Indiana University lowa State University The University of lowa
Kansas State University

The University of Kansas Loyola University Marquette University Michigan State University The University of Michigan University of Minnesota University of Missouri Northwestern University University of Notre Dame
The Ohio State University Ohio University

The Pennsylvania State University Purdue University Saint Louis University Southern Illinois University The University of Texas at Austin Washington University Wayne State University The University of Wisconsin

\section{NOTICE}

This report was prepared as an account of work sponsored by the United States Government. Neither the United States nor the United States Department of Energy, nor any of their employees, nor any of their contractors, subcontractors, or their employees, makes any warranty, express or implied, or assumes any legal liability or responsibility for the accuracy, completeness or usefulness of any information, apparatus, product or process disclosed, or represents that its use would not infringe privately-owned rights. Mention of commercial products, their manufacturers, or their suppliers in this publication does not imply or connote approval or disapproval of the product by Argonne National Laboratory or the U. S. Department of Energy. 
Argonne National Laboratory

9700 S. Cass Ave.

Argonne, Illinois 60439

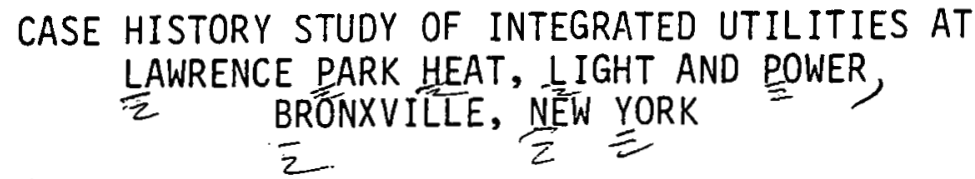

by

Chäles J.R. McClure \& Assoc. Inc. Consulting Engineers 2016 South Big Bend

St. Louis, Missouri 63117

prepared for

Energy and Environmental Systems Division

Argonne National Laboratory

under Contract 31-109-38-3826

September. 1, 1977

Work sponsored by

U.S. Department of Energy

Assistant Secretary for Conservation and Solar Applications

Buildings and Community Systems Divis:on, Community Systems Branch 


\section{Available from \\ National Technical Information Service 5285 Port Royal Road \\ Springfield, Virginia 22167}


Page

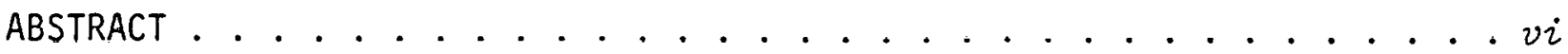

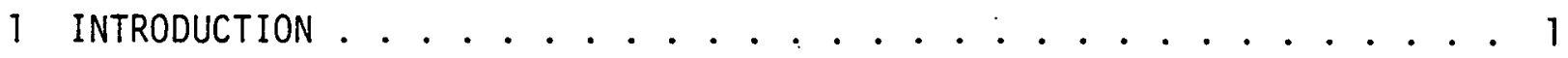

1.1 SCOPE OF PLANT SERVICES .................... 1

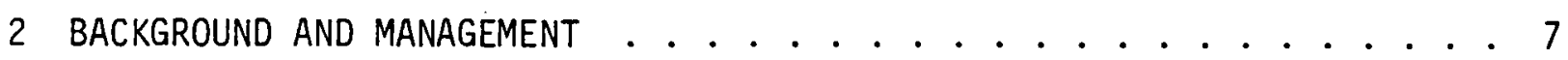

2.1 ORIGINAL OWNERSHIP . . . . . . . . . . . . . . 7

2.2 NEW ROCHELLE WATER CO. OWNERSHIP . . . . . . . . . . 8

2.3 CURRENT MANAGEMENT .................... . . . . 9

3 DESCRIPTION OF SYSTEM ..............................

4 PLANT PRODUCTION . . . . . . . . . . . . . . . . . 17

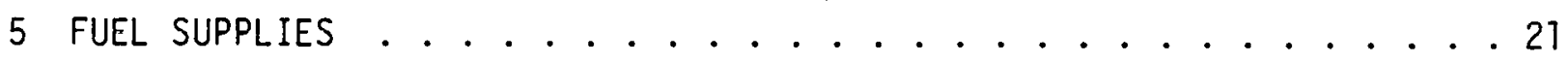

6 LABOR AND MANAGEMENT . . . . . . . . . . . . . . . . . 23

7 SYSTEM CONTROL . . . . . . . . . . . . . . . . . 25

7.1 REPORTING PROCEDURE . . . . . . . . . . . . . 25

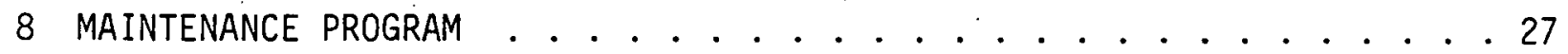

9 FINANCIAL . . . . . . . . . . . . . . . . 29

10 REGULATORY CONTROL . . . . . . . . . . . . . . . . 31

11 PeRfORMANCE EVAlUATION . . . . . . . . . . . . . . . . . . . 33

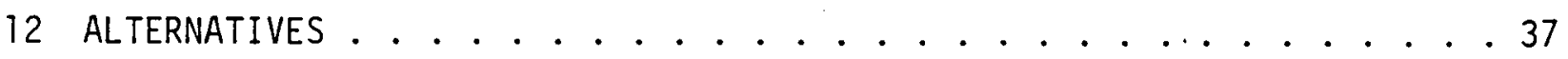


№.

1.1 Plan of Steam System Network . . . . . . . . . . . . 2

1.21975 Electric Production . . . . . . . . . . . . 3

1.31976 Electric Production . . . . . . . . . . . . 3

1.41975 Steam Production . . . . . . . . . . . . . . . 4

1.51976 Steam Production ................. . . 4

1.6 Daily Electric Load Profile . . . . . . . . . . . 5

1.7 Daily Steam Load Profile . . . . . . . . . . . . . 5

3.1 System Flow Diagram . . . . . . . . . . . . . 12

3.2 Machinery Locations in the Plant . . . . . . . . . 13

3.3 Lawrence Park Power Plant Floor Plan . . . . . . . . . . . 14

3.4 Electric Distribution System Diagram . . . . . . . . . . . 16

11.11976 Current Operating Mode .................. 34

11.2 Purchased Power - Local Individual Boilers . . . . . . . . . 35

11.3 A11 Purchased Power - Al1 Electric Heat Except Lawrence Hospital . . 35

11.4 Steam Heating Plant -- Purchased Power . . . . . . . . . . . 36 


\section{LIST OF TABLES}

No.

Titte

Page

4.1 Lawrence Park Performance Failures, 1976-1977 . . . . . . . . . . 17

4.2 Lawrence Park Heat, Light and Power Co. Steam Production Data,

1972 -- 1976 ........................ 18

4.3 Lawrence Park Heat, Light and Power Co. Product Sales Data,

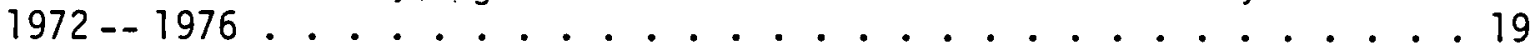

5.1 Lawrence Park Heat, Light and Power Co. Fuel $0 i 1$ Costs . . . . . . 21

9.1 Lawrence Park Heat, Light and Power Co. Cash Flow, 1972 -- 1975 . . 30

9.2 Energy Unlimited and Subsidiary, Consolidated Statement . . . . . . 30 


\section{ABSTRACT}

This report evaluates the Total Energy electrical generating system of the Lawrence Park Heat, Light, and Power Co. Included in the evaluation are the areas served, overall performance, costs, and finally, possible alternatives. 
Lawrence Park Heat, Light and Power Company is a sma11, privately owned, regulated public utility in Bronxville, New York, a suburb in Westchester County, adjacent to New York City. For more than 60 years, the company has furnished steam and electricity to a neighborhood of residential and sma11 commercial customers, and steam to a community hospital. Until 1965, the plant also served the area with a water system that included wells, pumps, a distribution system, and fire hydrants. From the beginning, the plant was an integral part of the real estate development of Bronxville, controlled by the Lawrence family. Construction of the fine apartment houses, the Gramatan Hotel, and incidental shops and offices in the vicinity of the station on the railroad leading into Manhattan was a grand scheme. The remote location required self-sufficiency in uti1ity service; so the developer met this need with the coal-fueled steam power plant.

Power for the water pumps and direct-current generators was obtained from the steam plant, as was common in those times.

\subsection{SCOPE OF PLANT SERVICES}

The Steam Distribution System plan, shown in Fig. 1.1, details the present extent of the areas served by the company -- areas that comprise a very stable community. The abandonment and demolition of the Gramatan Hotel constitute the most significant change in loads in decades. High-pressure steam (100 psig) is delivered to the hospital, and the same pressure is distributed to pressure-reducing stations in two remote manholes to boost the low-pressure steam service lines. Electric distribution (480 V) is underground, except for one overhead line parallel to the railroad tracks. The concealed electric cables were an early aesthetic consideration, and most of the cables are run through wood stave pipe from manhole to manhole, roughly parallel to the steam piping and in the same easements.

Currently, the company serves 410 electric customers and 138 steam users. Annual electric sales for 1976 totalled 2,923,614 kWh and produced $\$ 266,860.35$ revenue. Steam sales for the same period were 119,967 thousand pounds, producing revenues of $\$ 1,034,216.77$. The hospital is the largest steam customer and represents about $30 \%$ of steam sales; however, it buys electricity from the Consolidated Edison Company of New York, which serves all the adjacent territory in the Bronxville area. 


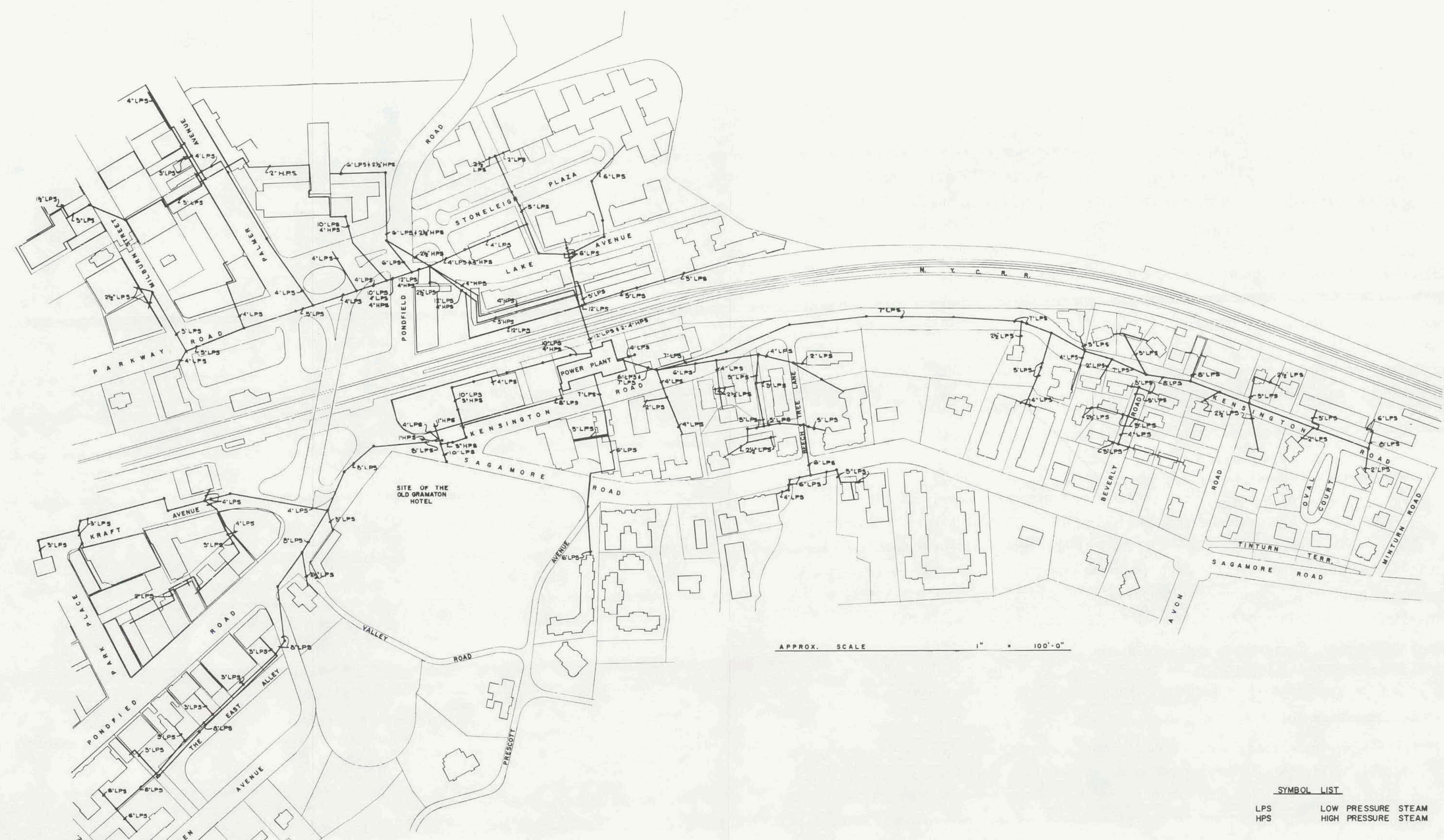

FIG. 1.1: Plan of Steam System Network 
Annual production of electricity follows the seasonal load variations incident to the need for electric air conditioning. As indicated in Figs. 1.2 and 1.3 the severity of weather causes short peaks in mid-summer. Data for these graphs have been derived from daily plant production logs and summation of customer billing. The smoother 1976 graph is the result of rational adjustment of the billing data and fuel use information to eliminate apparent errors in source data.

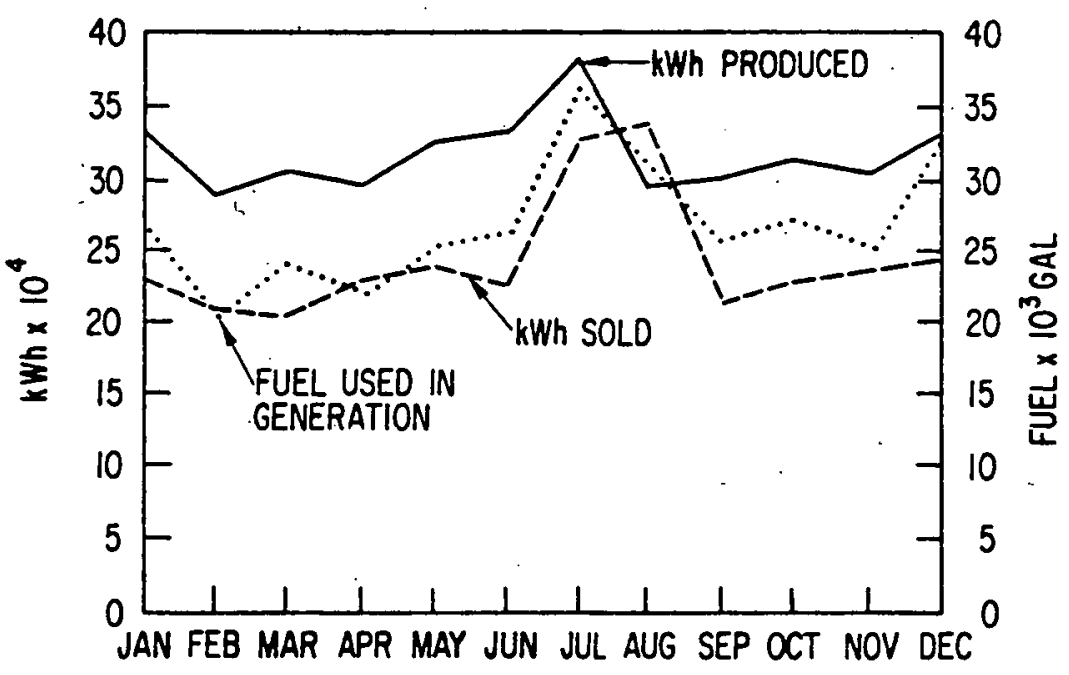

Fig. 1.2: 1975 Electric Production

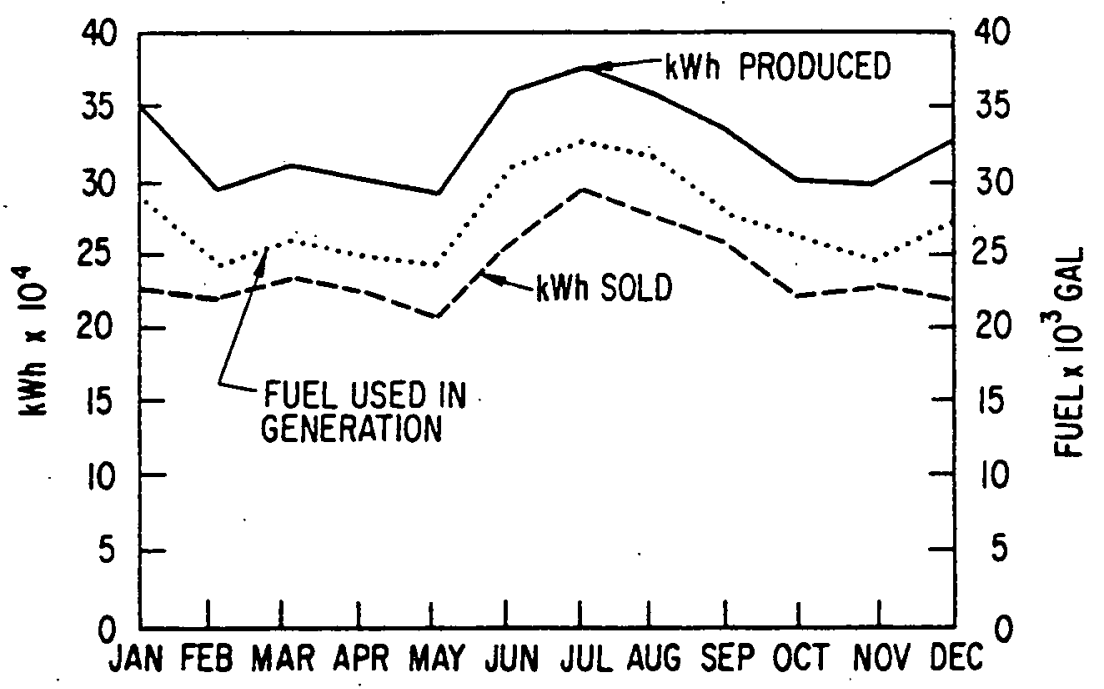

Fig. 1.3: 1976 Electric Production 
Figs. 1.4 and 1.5 show that heat steam sales are directly related to weather, except for the domestic water heating loads and one absorption chiller load.

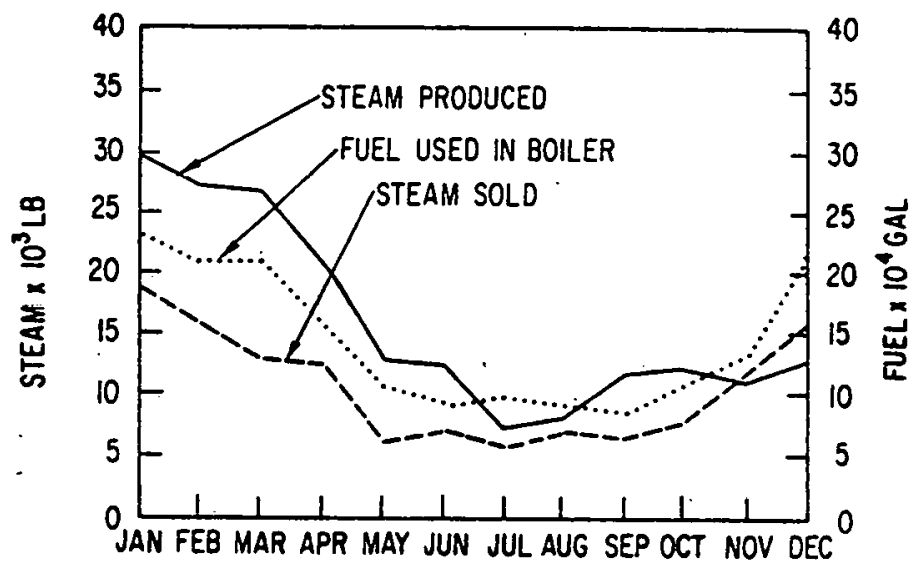

Fig. 1.4: 1975 Steam Production

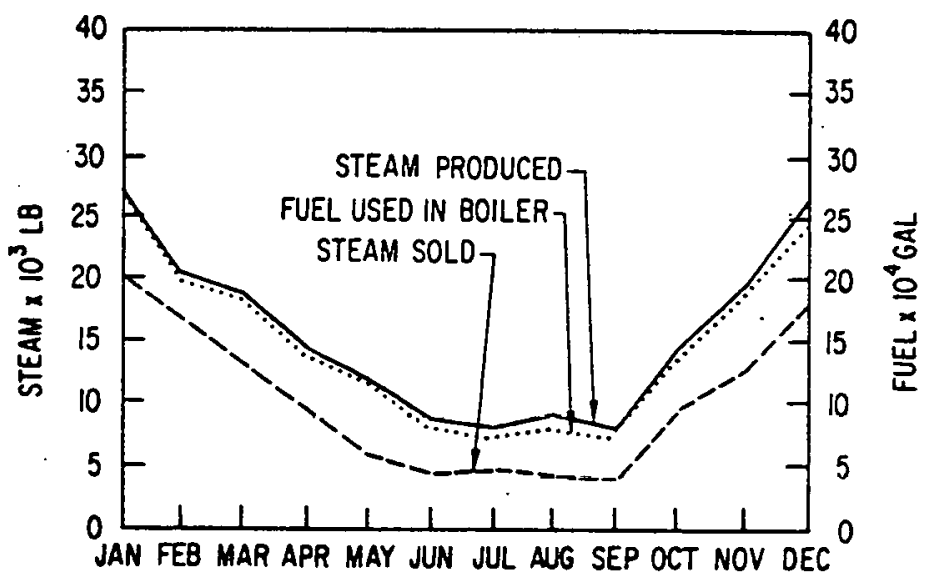

Fig. 1.5: 1976 Steam Production

Steam production is measured inaccurately from feedwater flowmeters because the boiler nozzle steam flowmeters have been inoperative for years. Daily operating logs kept by the boiler operators show feedwater meter readings, but the steam obtained from diesel engine generator set heat recovery is unmetered, as is the blowdown and other losses from the boiler system. Because flow through the feedwater meters often is intermittent and varies widely, the measurement accuracy is poor. Consequently, the data show that this plant sometimes sells more steam than it produces; attempts to identify efficiency of fuel use are frustrated. 
Daily plant. loads for several representative days have been accumulated in Figs. 1.6 and 1:7. Winter season electric use is uniform from day to day; but summer usage ranges from 500 to $1200 \mathrm{~kW}$ from early morning to noon, in response to the window air conditioners common to this vintage of apartment houses.

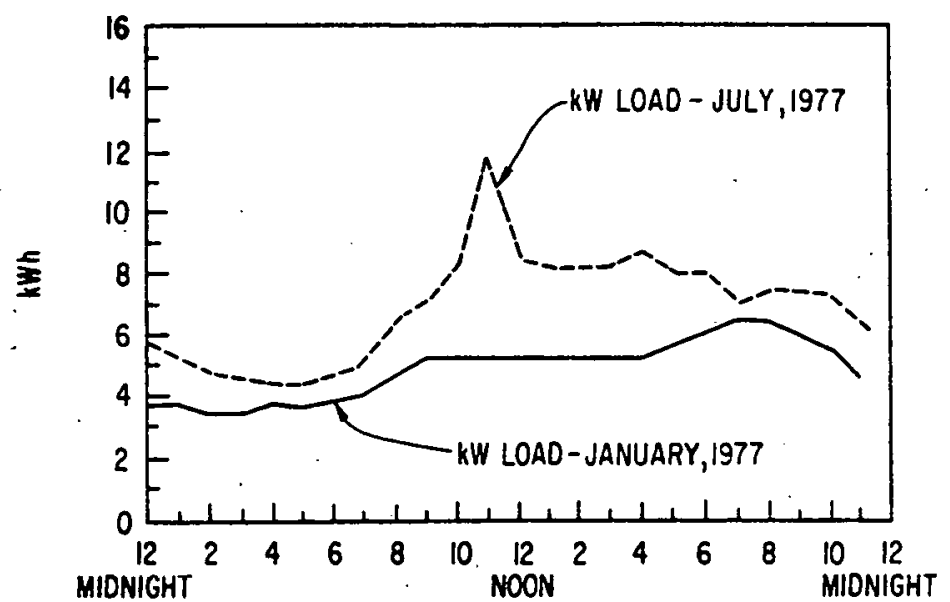

Fig. 1.6: Daily Electric Load Profile

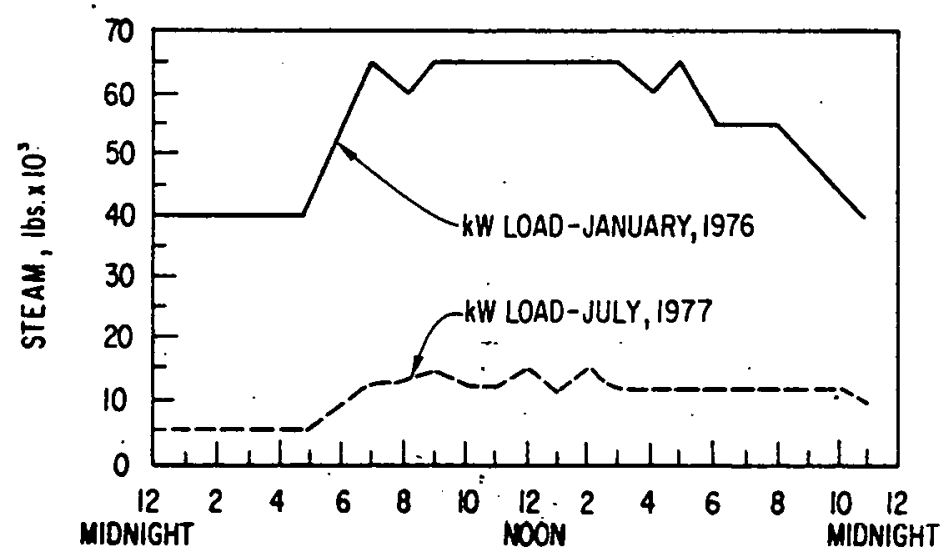

Fig. 1.7: Daily Steam Load Profile

Summer use of steam reflects the hospital laundry and absorption chiller loads; output varies from $5000-15,000 \mathrm{lb} / \mathrm{h}$. Winter steam load peak is reached in early morning and remains high all day. The decline in load in the evening is from night setback controls in the apartment and lower level use in the hos: pital. 


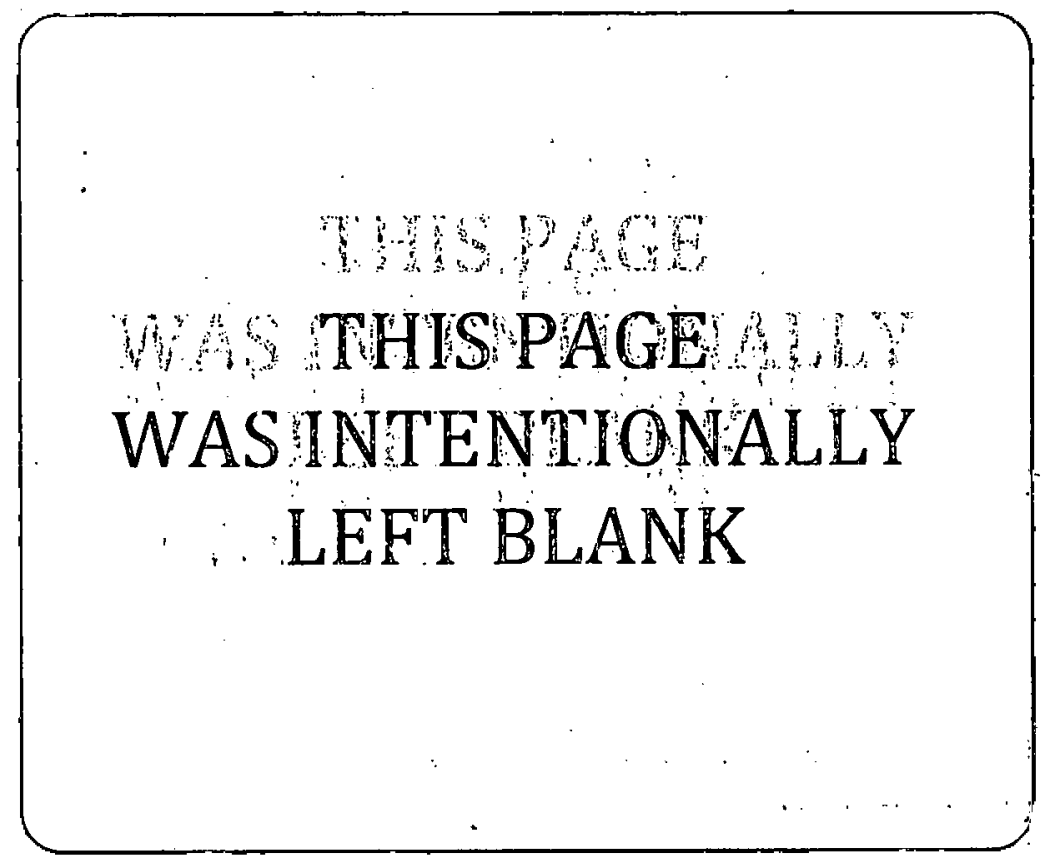




\section{BACKGROUND AND MANAGEMENT}

\subsection{ORIGINAL OWNERSHIP}

Before the turn of the century, a hotel and its power plant were in operation in Bronxville, but both were destroyed by fire. The present stone power plant building was constructed in about 1905 to serve the rebuilt Gramatan Hotel and the new apartment buildings. Most of the property and the plant were developed and owned by the Lawrence family. Public utility power was brought into the area in about 1905, but the on-site generation business was profitable to the owner and remained in service. As the public utility (Westchester Lighting Co.) in the area grew, there were more pressures to sell the isolated plant, and the Lawrence family reviewed the economics periodically. Plant operating personnel saw the matter as a simple competitive business, and morale was high even though the work was hard.

Plant fuel was. Pennsylvania bituminous coal, delivered by rail to the power plant siding and handled by manpower only. Firemen worked six 12-hour days per week and shoveled 8 or 10 tons of coal per man per shift. Electric power was all direct-current, and the advent of radios requiring alternating current was a great burden to the plant. Until about 1940, apartment dwellers were provided with $1500 \mathrm{Wdc} / \mathrm{ac}$ converters (motor-generator units) so they could use al: ternating-current appliances.

Mr. Louis Sands was employed as a fireman at the plant in 1916; he then became the chief engineer of Lawrence Park Heat, Light and Power Co., and ran the plant and dealt with the Lawrence Investment Company in all requests for capital improvements and plant operating expenses. The business of billing and collecting for services was handled by the business manager of the other real estate operations. Under Sands' direction, the power plant became a model of efficiency; it was the subject of trade publication articles in 1928 and 1940. Mr. Sands, still active and alert in 1977, competed successfully as a combined utility plant operator against Westchester Lighting and its successor, Consolidated Edison, until he retired in 1962. To control costs, most of the plant equipment was pur chased second-hand. The plant staff manufactured its own repair parts and directed all installation and maintenance work. Stokers were installed in 1928 to burn cheaper coal. Reciprocating steam engines powered the $100 \mathrm{~kW}$ and two 50 $\mathrm{kW}$, de generators. Competitive pressures from Consolidated Edison forced the major revisions in 1940 when ac generators were installed. 
As the plant load grew with new real estate developments, Sands extended the steam, electric, and water distribution systems. Steam piping was run underground in direct burial with magnesia insulation wrapped with roofing felt. Manholes were constructed at frequent intervals to provide access to packed expansion joints and valves. Vacuum pumps were installed on the return lines, and an elaborate zone valve control scheme was provided to limit overheating of the apartments. Steam-engine-driven generators and pumps were arranged to exhaust at 7 psig to the heating steam mains and boiler feedwater preheater. Combustion air blowers also were steam powered. With Sands in charge, the plant served the community for more than 15 years with NO shutdown or power interruption until April 24, 1940. On that date, a mechanical failure in \#4 steam engine, shut down the plant for $28 \mathrm{~min}$.

To reduce steam exhaust in summer, some electric motor drives were installed in the plant, and a $250 \mathrm{~kW}, 514 \mathrm{rpm}$ Buckeye Diesel Engine Generator was installed about 1945, but the plant stayed on a coal fuel basis until about 1961. Increased labor costs, unionization of the plant, complaints about soot and flyash all combined to make a change to fuel-oil firing necessary.

\subsection{NEW ROCHELLE WATER CO. OWNERSHIP}

In 1960, the extensive community water system was sold to New Rochelle Water Co., a division of General Water Works Co. Because the original wells were beginning to fail, soon the new owners had to switch the supply to their large county-wide system. After the plant was converted to oil firing, the General Water Works Co. bought the steam and electric system also and took over all operations of the plant. The new owner was experienced in utility system management and had been operating as a public service commission regulated company for some time. Sands retired in 1962, and a succession of operators took on the responsibility for performance of the plant.

The new owner allowed the physical plant to deteriorate. Because most of the equipment was old it required a lot of repair and attention from skilled mechanics who were no longer available. Plant performance also deteriorated, and customer complaints to the owner were not effective. The New York State Public Utility Commission made several attempts to require improvements in the quality of service provided, but they were unsuccessful. By 1971 , the Lawrence Park Heat, Light and Power Co. was a tragedy in the daily life of the people 
served by the plant. Electric service often was interrupted, delivered at erratic voltage and frequency and of such limited capacity that no increase in appliance loads by customers was permitted. Steam service was more reliable, but the underground piping was leaking at many places, and vapor plumes obstructed traffic. Steam leaks killed ornamental plantings, and there was no sign of future improvement. General Water Works Co. reported a loss of over $\$ 400,000$ in 1971 in the operation of Lawrence Park Heat, Light and Power Co.

Some of the power plant customers called on a new firm, Energy Unlimited, Ltd. of New Britain, Connecticut, to obtain some relief from the situation. Introduction of this new firm required approval of the state regulatory agency, and the Public Service Commission (PSC) required assurance that the new owner could finance the required emergency improvements. At the direction of the PSC, General Water Works agreed to sell the stock in Lawrence Park Heat, Light and Power Co. to Energy Unlimited, Ltd. for $\$ 1.00$ provided the new owner would spend not less than $\$ 700,000.00$ to recondition the facility and would then operate it as a: regulated utility. This arrangement resulted in very extensive changes in the pilant personnel, management, equipment, and business practices.

\subsection{CURRENT MANAGEMENT}

: In 1973, the changes by the new management began to become obvious and were: largely in place by the end of 1974. This owner was a profit-oriented, energy systems management firm that instituted a major technological change in plant production by installing diesel-engine generators with heat recovery to produce all the electricity required. Further improvements to the electrical distribution system, a new steam boiler and repair or replacement of defective steam distribution components have been accomplished. These changes have reduced plant fuel consumption remarkably as is evident in the tabulations on page 18.

Coincident with the technical improvements, the new management introduced a forgotten element of the business, customer relations, and began to meet with customers to resolve their disputes. Metering changes, adjustment of improper invoices, repairs to service entrances, and similar corrections changed most of the customers from enemies to willing customers. New and higher rates for electricity and steam have been instituted after approval of the Public Service Commission. Technical support for the plant operators has been improved and, with 
the improved plant equipment, the staff has largely regained the reputation of providing reliable service to the community.

Lawrence Park Heat, Light and Power Co. has again become a profit opportunity for an alert and competent operator. The deleterious effects of time and lack of timely repairs are still serious; most of the plant physical facility is in poor condition, and a great deal more effort and money must be spent to get the plant in good condition. Nevertheless, there is an interested and competent management in charge, and there is some basis for expecting the situation to continue to improve. 


\section{DESCRIPTION OF SYSTEM}

Steam production facilities of the Lawrence Park Heat, Light and Power Co. have remained substantially the same for the last 15 years. In 1975, the No. 4 boiler was replaced with a new forced-draft, fire tube 27,000 1b per hour oil-burning unit. The steam pressure reducing capacity in the plant was greatly increased in 1976, and a deaerating feedwater heater with electric drive feedwater pumps was installed in 1974. Steam headers and valving have been unchanged for years. When the new engine-driven generators were added in 1973 and 74 , the low-pressure steam piping and condensate return systems were revised to accomodate the engine heat recovery systems, and another cooling tower was added to dissipate aftercooler and lube oil heat. The system diagram in Fig. 3.1 shows the present plant configuration; fig. 3.2 illustrates the machinery locations in the plant; fig. 3.3 shows the steam distribution system serving all 64 commercial and 74 residential customers.

Much of the underground steam piping was in poor condition in 1972, and there have been numerous repairs and replacements. Condensate returns are in particularly bad shape, and little condensate is actually returned from heating loads. All the piping is direct burial, and much of the insulation has deteriorated to the point of being ineffective.

The power plant building is in particularly poor condition. Wood frame roof materials have decayed; door and window frames are rotten; glass is broken; and the general appearance is that of a slum. There is a 175-ft-high masonry chimney in fair shape, and this serves to dissipate the combustion products high above the community.

Fuel oil is stored in two above ground 50,000-gal capacity tanks. One is reserved for No. 2 oil for the diesel engines and the other serves the boiler burners. Boiler fuel for the past several years has also been No. 2 oil, but the system is suitable for No. 4 , No. 5 or No. 6 oil also, and the product purchased is chosen on economic grounds. Recently, the price of heavy fuel oil has reduced, and the plant promptly changed to take advantage of this reduction.

Conversion of the plant from 208 to 480 -volt production and distribution is still not complete. This transition has required a careful step-by-step procedure that included: 


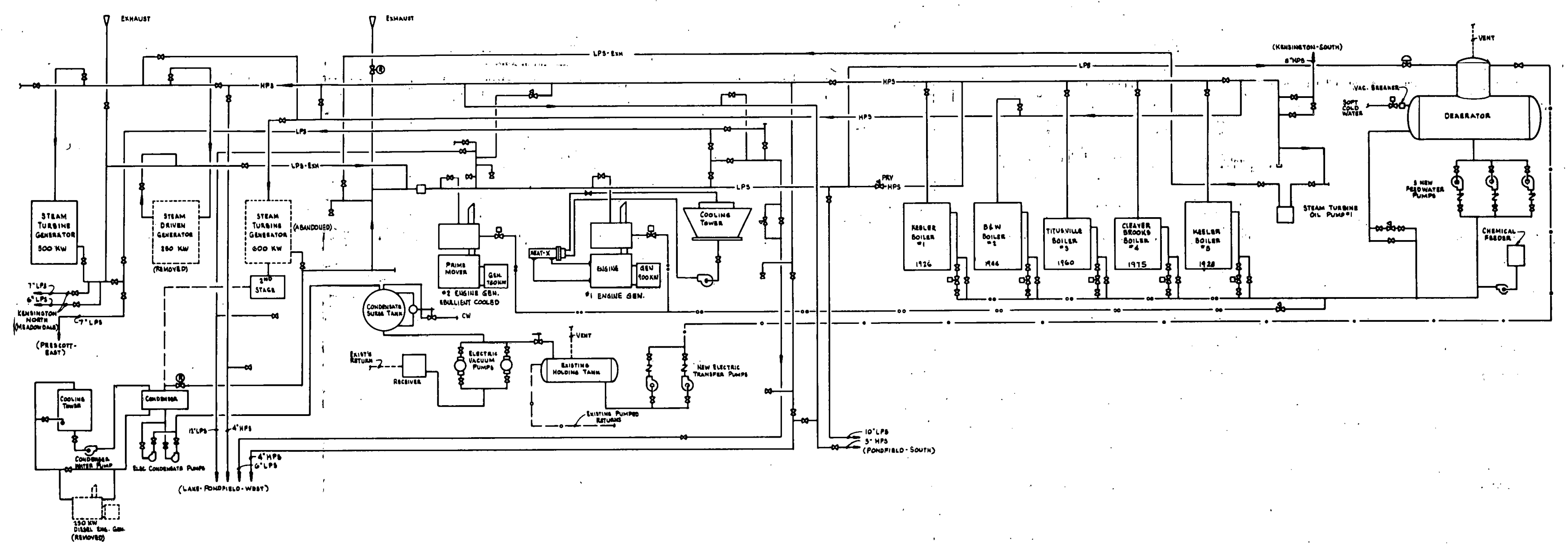

FIG. 3.1: System Flow Diagram 


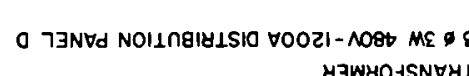

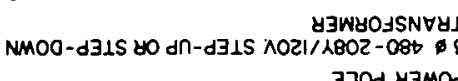

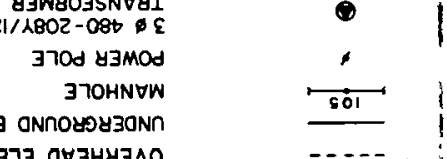

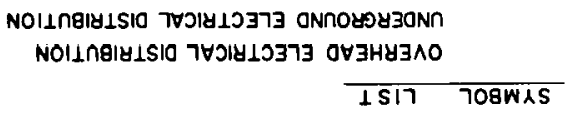

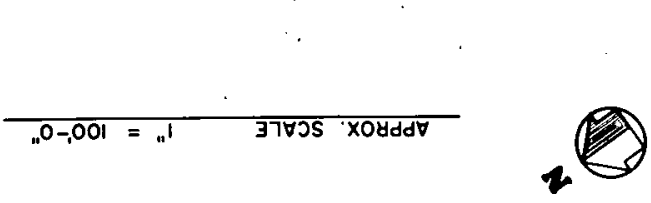

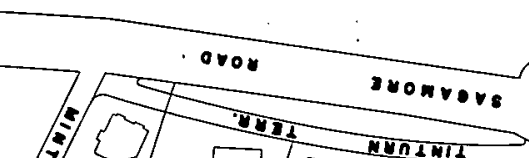

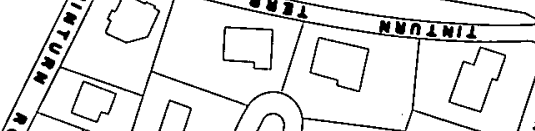

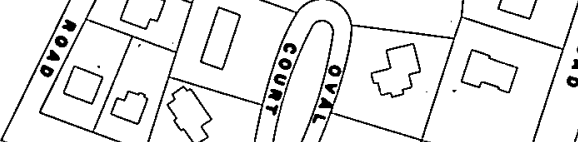

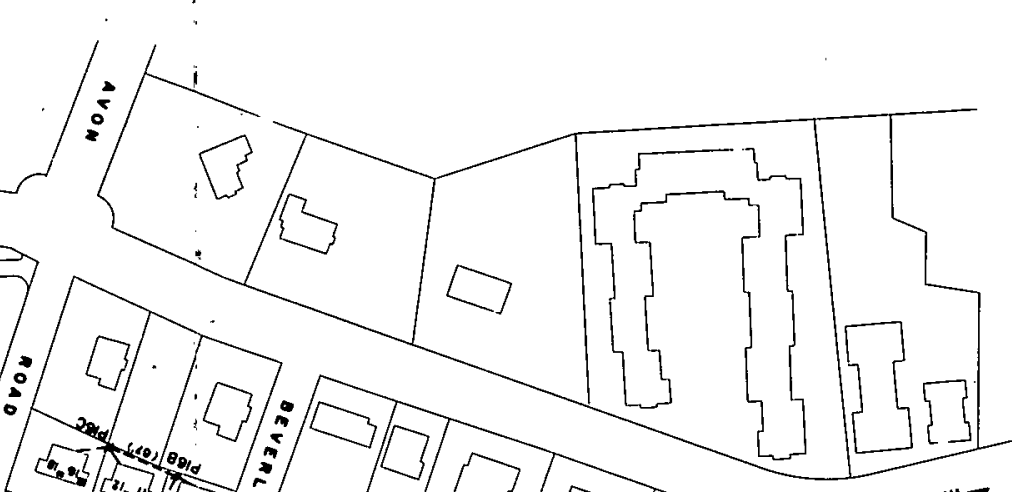

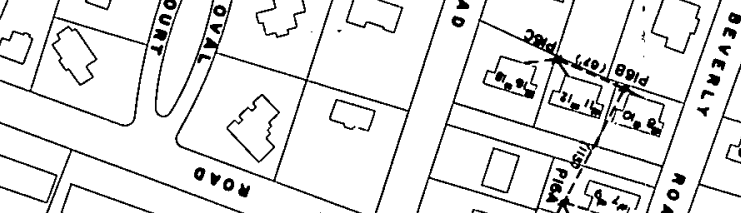
(5)

(x) mon ho3200

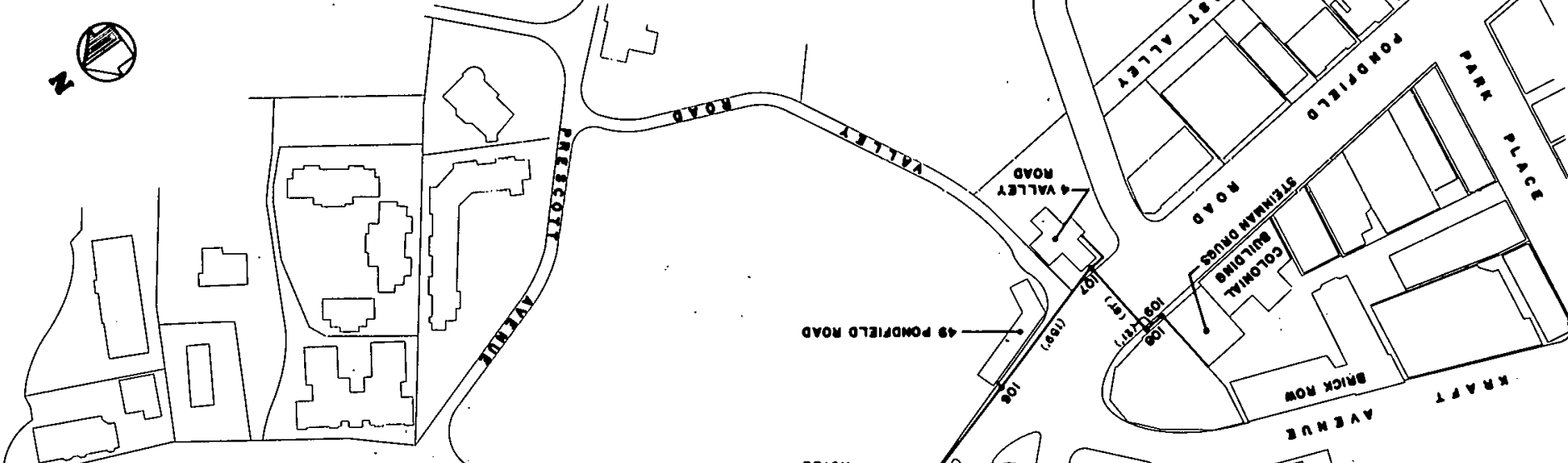

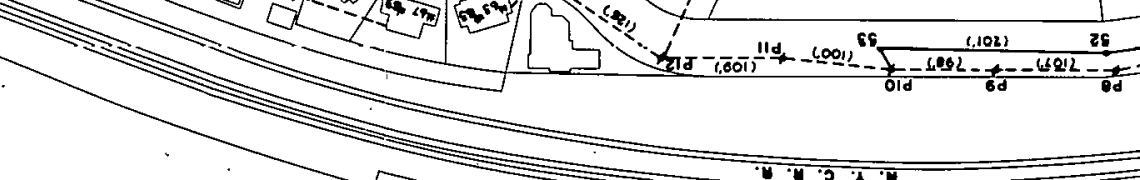

$1=12=10$
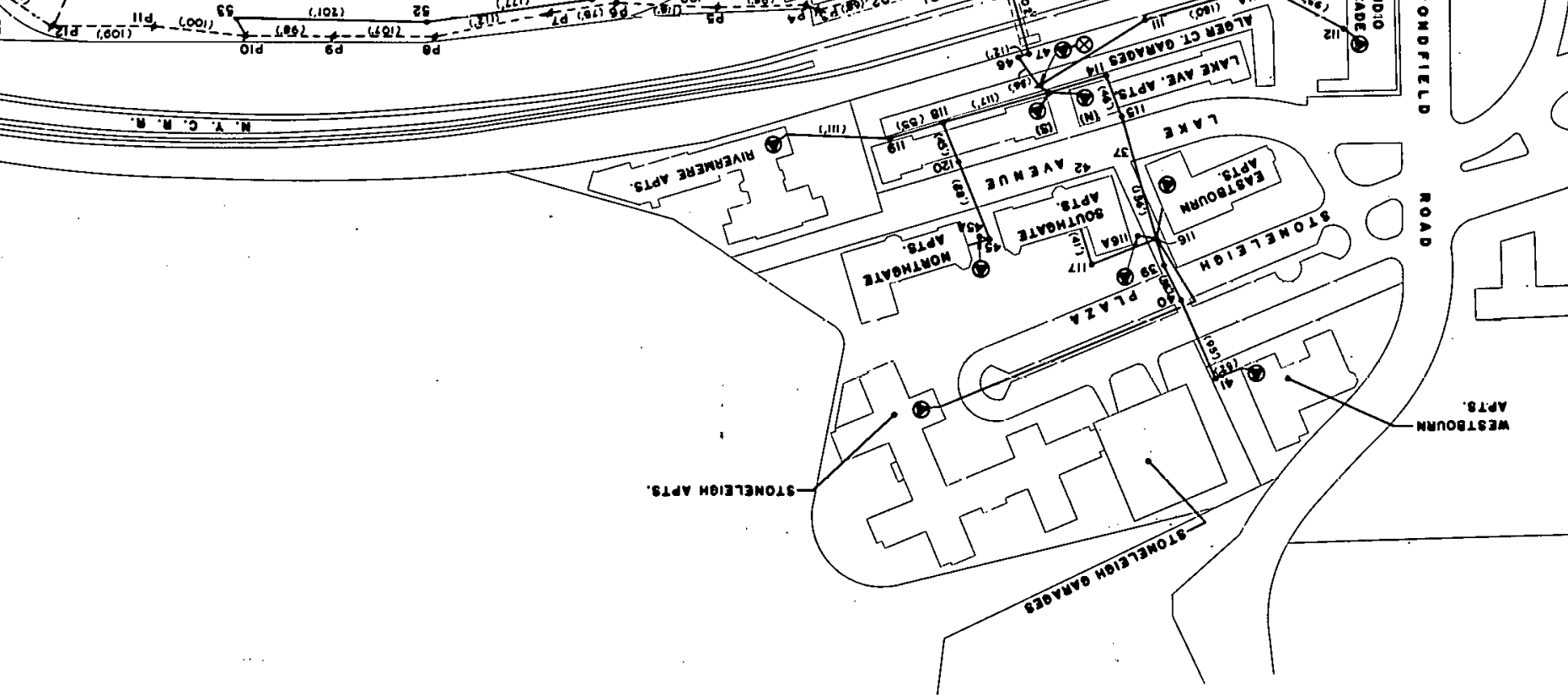


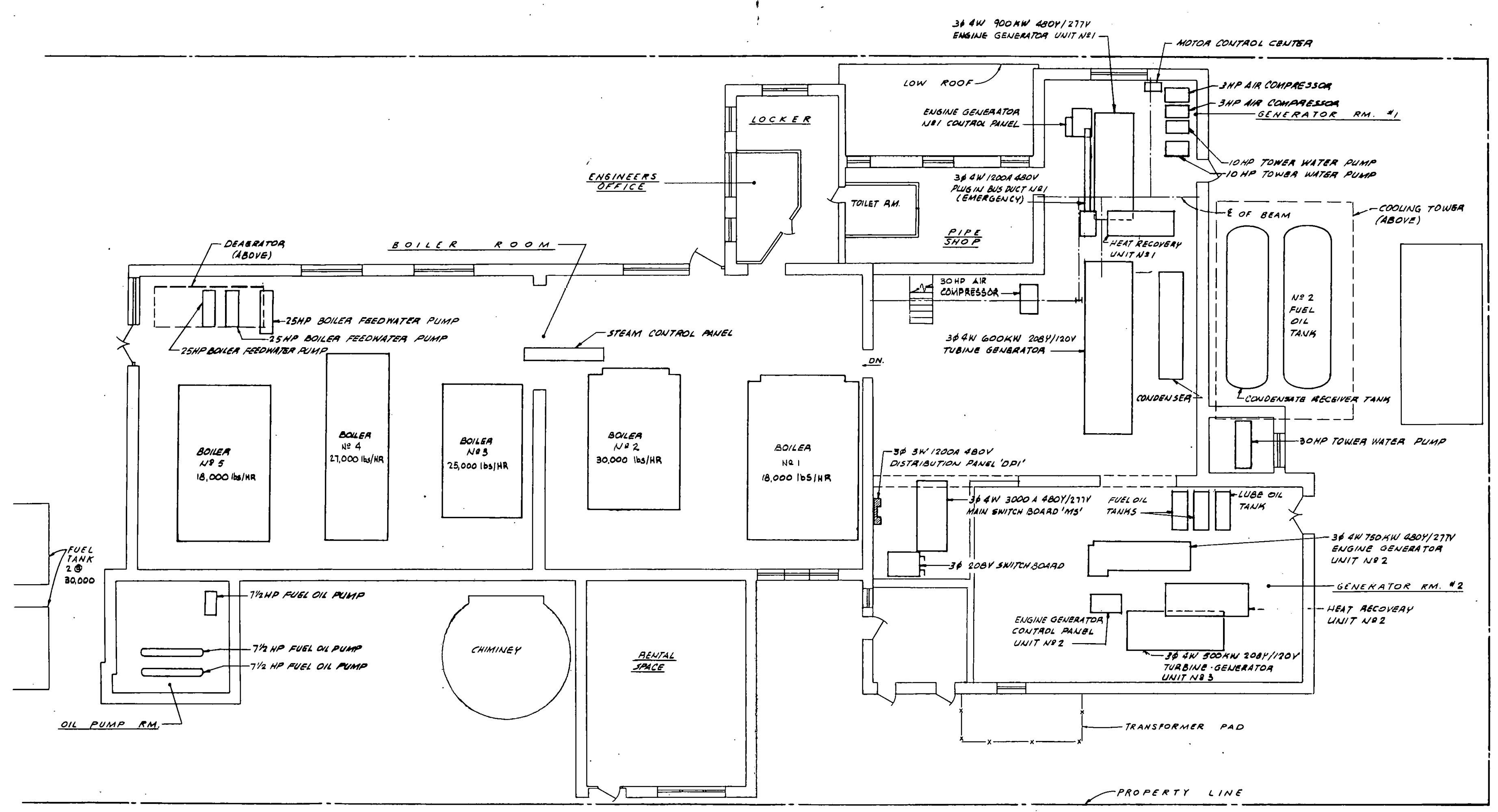


1. Establishing a $480-\mathrm{V}$ bus connected to $208 / 480 \mathrm{~V}$ transformers;

2. Installing a $480 \mathrm{~V}$ generator;

3. Testing existing $208 \mathrm{~V}$ feeders for use at $480 \mathrm{~V}$ and replacing unsuitable cables;

4. Installing $480 / 208 \mathrm{~V}$ transformers at existing service entrances and temporary reconnecting of feeders to $480 \mathrm{~V}$ bus;

5. Replacement of $208 \mathrm{~V}$ power distribution switchboard in the power plant with $480 \mathrm{~V}$ switchboard and reconnection of $480 \mathrm{~V}$ feeders; and

6. Replacement of $208 \mathrm{~V}$ generator on $500 \mathrm{~kW}$ steam turbine with $480 \mathrm{~V}$ generator.

The map, page 13 shows the areas served by the distribution system and the location of the 340 residential and 70 commercial customers served by the plant.

With present loading, the operators normally run the No. 2 engine generator continuously and serve a 11 loads up to about $700 \mathrm{~kW}$. When the load exceeds this level, the No. 1 machine is paralleled and the two units share the electrical load. Since the No. 1 unit is not equipped with jacket water heat recovery, the use of this machine is avoided. The $750 \mathrm{~kW}$ capacity No. 2 machine has full heat recovery from both exhaust and jacket coolant in an ebul1ient system operating at 12 to 15 psig steam. Engineering planning anticipated use of the No. 1 unit as a standby machine rated at $900 \mathrm{~kW}$ and provided only exhaust gas heat recovery, at 12 to $15 \mathrm{psig}$ steam, so as to permit engine operation at $180^{\circ} \mathrm{F}$. The engine manufacturer derates the machine when operating temperatures exceed $180^{\circ} \mathrm{F}$.

Because No. 4 boiler is much more efficient and dependable than the older units, this unit is base-loaded at all times. This boiler also has the widest range of burner turn down so that it performs well at low loads. Other boilers are used only when the load is too great for No. 4 .

Fig. 3.4 illustrates electrical generation and distribution. The plant has evolved to $480 \mathrm{~V}$ generation in the past four years, although the remaining steam turbine driven generator is sti11 a $208 \mathrm{~V}$ machine. When the steam driven unit must be used, its output is 1 imited to the small remaining $208 \mathrm{~V}$ loads plus the capacity of the $300 \mathrm{kVa} 480 / 208 \mathrm{~V}$ transformer. 


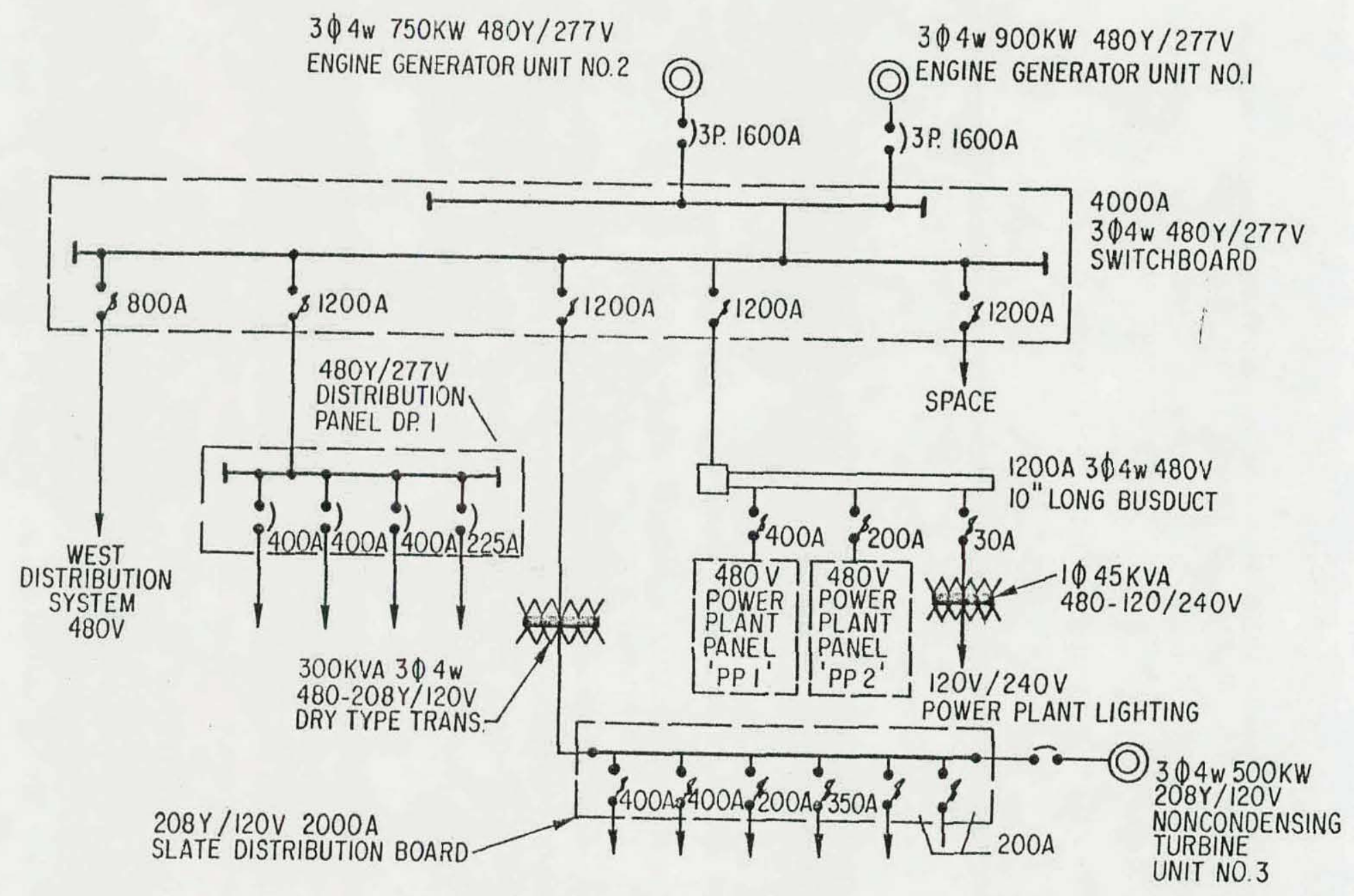

FIG. 3.4: Electric Distribution System Diagram 


\title{
4 PLANT PRODUCTION
}

Despite the delapidated condition of the power plant, the customers have had adequate service for the past several years. Lawrence Hospital is the largest steam customer and is dependent entirely on Lawrence Park Heat, Light and Power Co. for space heating, sterilizing, kitchen and laundry steam, and domestic water heating. Although the hospital occasionally has disagreed with meter readings and resultant invoices, it has nevertheless, repeatedly complimented the plant, in writing, about the reliability of service. There is currently an expansion of the hospital under construction, and a part of the scope of work is the expansion of the utility steam service entrance facility and a renewed commitment to the plant as a sole source of steam.

Electrical customers have had a recent demonstration of their benefits from being served by an independent power source. Consolidated Edison's massive blackout in July, 1977, plunged the surrounding neighborhoods into darkness for many hours, but the area of Bronxville, served by the plant, continued to function without incident.

Of course, there have been outages, although the company records do not indicate any system shutdowns in the past year. Service outage reports are submitted by the plant operator to the company management, and any total outage of more than $15 \mathrm{~min}$ is supposed to be reported to the Public Service Commission. No record of total failures could be found. Listed in Table 4.1 are the performance failures noted by the plant operators since December, 1976.

\author{
TABLE 4.1 LAWRENCE PARK PERFORMANCE FAILURES, 1976-1977 \\ $12 / 23 / 76 \quad$ Steam pressure low all day. \#3 boiler lost tubes; \#1 fuel pump \\ failed; $\sharp 4$ boiler experienced flame failure \\ cause: bad batch \#6 oil \\ $12 / 25$ - 31/76 Steam pressure varied - $\# 3$ boiler out of service; continued in- \\ terruption of burners because of flane failures \\ cause: bad oil \\ $1 / 1-7 / 77$ Steam pressure lost when feed water pump failed \\ $1 / 30-2 / 5 / 77$ Steam pressure low for 4 hours \\ cause: bad oil \\ $7 / 30 / 77$ Hillcrest area electric feeds out for 10 hours cable failure \\ underground \\ 8/3/77 Electrical feeder failure between $M H 18$ and $19 A 2$ hour outage \\ for 3 apartment buildings; 4 hour outage for Hillcrest apart- \\ ments \\ cause: sewer leakage into manhole
}


Area residents are accustomed to voltage regulation problems from the utility grid. Because distribution networks in New York are operated at the limits of capacity on many occasions and high voltages occur in low load times, low voltages are imposed on the customers to reduce loads in some areas. Lawrence Park Heat, Light and Power Co. does not reduce voltage for this purpose and delivers almost constant $480-V$ power. Some feeders have more voltage drop than others, but the delivered service is within the range of $5 \%$ of nominal rating. Since the majority of customers are served at 208/120 volts, the local transformer taps may be set to accommodate the length of feeder.

Although customer complaints to the plant operator are not generally recorded, operators recall some neighbors who have complained about noise from the plant, escaping steam from manholes, and the unsightly condition of the plant building. No records exist of official citations for environmental violations.

Steam production data, shown in Table 4.2, are probably inaccurate because of deficient metering. Fuel consumption figures normal1y are checked against deliveries and are more nearly correct. The steam production figures may have been derived by the operators by applying an assumed fuel conversion efficiency to the measured fuel consumption. Electrical production figures are more accurate except when the \#1 engine generator is used. This machine has a defective Watt-hour meter, but the unit is used only as a reserve power source.

TABLE 4.2 LAWRENCE PARK HEAT, LIGHT AND POWER CO. STEAM PRODUCTION DATA, 1972 -- 1976

\begin{tabular}{|l|c|c|c|c|c|}
\hline & 1972 & 1973 & 1974 & 1975 & 1976 \\
\hline STEAM PRODUCTION & 386,849 KALS & 324,060 KALS & 251,498 KALS & 193,775 KALS & 181,798 KALS \\
Gallons fuel used & $3,572,162$ & $3,050,216$ & $2,001,890$ & $1,756,612$ & $1,755,637$ \\
lbs steam/gal fue & 108 & 106 & 126 & 10 & 104 \\
Boiler eff. & $76 \%$ & $75 \%$ & $88 \%$ & $78 \%$ & $73 \%$ \\
kWh PRODUCTION & $3,967,600 \mathrm{kWh}$ & $4,309,000 \mathrm{kWh}$ & $3,544,000 \mathrm{kWh}$ & $3,853,360 \mathrm{kWh}$ & $3,925,120 \mathrm{kWh}$ \\
Gallons fuel used & & $143,377^{*}$ & 285,238 & 326,657 & 327,738 \\
KWh/gal fuel & & 12 & 12.42 & 11.8 & 11.98 \\
Engine gen. eff. & & $30 \%$ & $31 \%$ & $29 \%$ & $30 \%$ \\
\hline
\end{tabular}

* Fuel used in production of $1,720,520 \mathrm{kWh}$ by engine generator. One KAL $=1000$ lbs of steam. 
Although product sales data, Table 4.3, are derived from customer meters, the business office provides interpretations and manual adjustments where the metered quantities deviate from rational values. In general, the records of steam and electric sales are accurate, and certainly the cost information is carefully reviewed by the customers.

TABLE 4.3 LAWRENCE PARK HEAT, LIGHT AND POWER CO. PRODUCT SALES DATA, 1972 -- 1976

\begin{tabular}{|c|c|c|c|c|c|}
\hline & 1972 & 1973 & 1974 & 1975 & 1976 \\
\hline STEAM SALES & 134,326 KALS & 127,527 KALS & 135,060 KALS & 126,287 KALS & 119,967 KALS \\
\hline $\begin{array}{l}\text { Gallons fuel used } \\
\text { lbs steam sold/gas fuel }\end{array}$ & $\begin{array}{r}3,572,162 \\
38\end{array}$ & $\begin{array}{r}3,050,216 \\
42\end{array}$ & $\begin{array}{r}2,001,890 \\
67\end{array}$ & $\begin{array}{r}1,756,612 \\
73\end{array}$ & $\begin{array}{r}1,755,637 \\
68\end{array}$ \\
\hline kWh SOLD & $3,461,089 \mathrm{kWh}$ & $3,544,000 \mathrm{kWh}$ & $2,900,843 \mathrm{kWh}$ & $2,948,160 \mathrm{kWh}$ & $2,923,614 \mathrm{kWh}$ \\
\hline $\begin{array}{l}\text { Gallons fuel used } \\
\text { kWh sold/gas fuel }\end{array}$ & & & $\begin{array}{r}285,238 \\
10.17\end{array}$ & $\begin{array}{r}326,657 \\
9.03\end{array}$ & $\begin{array}{r}327,738 \\
8.92\end{array}$ \\
\hline
\end{tabular}

One $\mathrm{KAL}=1000 \mathrm{lbs}$ of steam. 


\section{THIS PAGE WAS INTENTIONALLY LEFT BLANK}




\section{FUEL SUPPLIES}

Fuel oil quality standards in the New York area require the use of lowsulphur fuel. No. 2 oil used in the engines always is below the required sulphur level. Distributors of oil are prohibited from selling substandard No. 4, 5 or 6 oil in the area.

Lawrence Park buys oil at prevailing market prices on short-term agreements. The parent company also owns and operates a large fuel-0il distributing firm in Connecticut. All technical expertise concerning oil purchasing is used to the advantage of the power company. Fuel oil prices for the past four years are shown in Table 5.1 .

TABLE 5.1 LAWRENCE PARK HEAT, LIGHT AND POWER CO.

FUEL OIL COSTS

\begin{tabular}{|l|l|l|l|l|}
\hline & \multicolumn{1}{|c|}{1973} & \multicolumn{1}{|c|}{1974} & \multicolumn{1}{|c|}{1975} & \multicolumn{1}{|c|}{1976} \\
\hline STEAM & & & & \\
$0 i 1$ used - gat & $3,050,216$ & $2,001,890$ & $1,756,621$ & $1,755,637$ \\
Fuel cost & $\$ 422,014$ & $\$ 686,879$ & $\$ 609,852$ & $\$ 627,767$ \\
Fuel cost/ga1 & $\$ .1384$ & $\$ .3431$ & $\$ .3472$ & $\$ .3576$ \\
ELECTRIC & & & & \\
0 i1 used - ga 1 & $143,377(\mathrm{a})$ & 285,238 & 326,657 & 327,738 \\
Fuel cost & $\$ 34,399$ & $\$ 91,742$ & $\$ 115,207$ & $\$ 119,606$ \\
Fuel cost/gat & $\$ .2399$ & $\$ .3216$ & $\$ .3527$ & $\$ .3649$ \\
\hline
\end{tabular}

(a) Fuel used in production of $1,720,520 \mathrm{kWh}$ by engine generation.

Fuel costs are passed through to the customers in the form of fuel adjustment factors on monthly bills. The Public Service Commission monitors the price of fuel relative to other utility company costs. Fuel adjustment is calculated monthly by the company which considers the net fuel cost of producing the saleable product rather than a simple cost of fuel comparison. Improved efficiencies of plant performance are not accrued in full to the company.

Fuel cost adjustment is a substantial portion of the selling price of electricity and steam. The formula to determine the factor includes a significant multiplier for plant efficiency as reported for the previous year. Thus 
the plant that improves efficiency in the simple terms, $\mathrm{kWh} / \mathrm{gal}$ of fuel or Kals of steam/gal of fuel, receives the benefit of this improvement only for one year; thereafter, the improvement in efficiency applies only to the base cost of fuel. In the situation at Lawrence Park Heat, Light and Power Co., the base fuel cost is approximately $\$ .123 /$ ga 1 ; whereas, the current price of fuel is $\$ .365 /$ gal . Fuel use reductions from improved plant equipment or operations benefit the company as though the fuel still cost only $\$ .123 /$ gal.

When the plant was modified in 1973, the diesel engines were fueled with No. 4 oil, a lower cost, higher-heat-content light oil used extensively in metal heat treating operations in New England. The engines ran well on this fuel when it could be delivered through the fuel filter system, but the quality control of the No. 4 oil was found to be poor. Prefilters were installed to reduce the service problem, but the product often included heavy end, stringy non-fluids that clogged the filters in minutes. Investigation indicated that the industry was too careless about storage and delivery equipment cleaning to be relied upon to deliver No. 4 oil in the specified viscosity and sulphur content range. Since then, the engines have run on No. 2 oil exclusively. Coincidently, the price of No. 4 oil has risen to about the same price as No. 2. The boiler burners, four steam-atomizing and one air-atomizing type, can handle preheated No. 6 oil or lighter. Product prices have fluctuated considerably, and the company buys the lowest cost fuel.

Serious operating problems have been caused by poor No. 6 fuel quality -- see Table 4.2, performance failure tabulation of 1976-1977 winter experience. The oil storage tanks are exposed above ground, and only the suction pipe area is heated. In severe weather, the oil stored gets cold and very difficult to handle. 


\section{LABOR AND MANAGEMENT}

Plant operations are directed by the staff of Energy Unlimited, Ltd. from its Connecticut main office. A vice president of that company manages the operation of approximately six plants and uses a roving technical supervisor to supervise all plant functions. Weekly visits are made to the plant by either the vice president, the supervisor, or a staff engineer.

Power plant personnel staff comprise one chief engineer, four watch engineers, and two helpers, a total of seven men, each of whom works a normal 40-hr week.

The day shift, 8 a.m. to 4 p.m. Monday through Friday, is staffed with the chief engineer, a watch engineer, and the two helpers. They operate the plant, perform major repairs and maintenance, order materials, schedule work, provide water treatment and test, and clean boilers and engines.

The evening shift, staffed by one watch engineer, operates the plant, cleans and maintains cooling towers, maintains plant meters, and operates boiler blowdown and soot blowing.

The watch engineer, on duty from midnight to 8 a.m., operates the plant, greases machinery, tests stand-by equipment, cleans plant, and inventories plant supplies.

Two swing-shift men rotate through the schedule to provide for week-end attendance of at least one man per shift and fill-in for holidays, vacations, etc.

A11 plant personnel are represented by Local 30 Operating Engineers in New York. The union has been unable to provide staff, as needed, on many occasions, so the company recruits men who then get conditional union cards.

Wages for the operating staff in 1977 were:

$\begin{array}{ll}\text { Chief Engineer: } & \$ 398 \text { per week } \\ \text { Watch Engineer, day: } & \$ 8.30 / \mathrm{hr} \\ \text { Watch Engineer, 4- 12: } & \$ 8.45 / \mathrm{hr} \\ \text { Watch Engineer, 12 - 8: } & \$ 8.50 / \mathrm{hr} \\ \text { Helper: } & \$ 4.50 / \mathrm{hr}\end{array}$

Plant operators rely on the chief engineer for guidance, and standing orders require reporting a 11 outages and performance problems to the Energy Unlimited office. 
Billing, collecting, purchasing, payments and all other administrative functions are provided by the home office of Energy Unlimited. 


\section{SYSTEM CONTROL}

Because the plant is fully attended, boilers and generators are manually started and stopped, except for safety shutdown. The new \#4 boiler is fully automated, fires intermittently at low loads, and modulates burner capacity to maintain steam pressure at $125 \mathrm{psig.} \mathrm{The} \mathrm{other} \mathrm{boilers} \mathrm{are} \mathrm{in} \mathrm{such} \mathrm{condition}$ that they are used only when necessary and are then operated continuously. The burners and combustion air systems do modulate, but only to about $40 \%$ of capacity. All boilers are equipped with electronic flame failure protection, combustion air interlocking controls, and automatic water level controls with lowwater alarm and cut-off of burners.

The two diesel engine generators, when paralleled, are equipped for air start, automatic govenor control of frequency, and electronic load sharing. Generators are equipped with automatic voltage regulators and produce the same voltage throughout the load range. Each machine is equipped with drawout, air frame, electrically-operated load breakers with shunt trip feature; low voltage, overcurrent and reverse-power relays; automatic synchronization relay; over-speed, low oil pressure, coolant system failure; and vibration switches for automatic shutdown in unsafe conditions.

The remaining viable steam turbine must be manually started and slowly brought up to synchronous speed; a fly ball govenor controls inlet steam flow to maintain constant speed. The generator has a rotating exciter and manual adjustment of voltage. A drawout air frame breaker with overload protection safeguards the power feeder. The turbine is equipped with overspeed shut-down control. Turbine exhaust is connected to the low-pressure steam header, and a spring loaded relief valve vents steam to the atmosphere if there is insufficient steam load to use all that the turbine produces.

\subsection{REPORTING PROCEDURE}

The plant operator reports the following as his standard power generation procedure:

1) The $750 \mathrm{~kW}$ diesel is run with maximum load to recover as much waste heat as possible; the maximum load is $720-740 \mathrm{~kW}$ before the $900 \mathrm{~kW}$ is put on the line. The $900 \mathrm{~kW}$ would share the load with the $750 \mathrm{~kW}$ and only when the load on the $900 \mathrm{~kW}$ would exceed $800 \mathrm{~kW}$ would the $500 \mathrm{~kW}$ steam turbine be used. 
2) There are no load dump procedures set up at this plant; there are low voltage trips on a11 customer circuit breakers. In case of plant failure or problems, all customer distribution would be interrupted, and the plant would take priority. Customers would be restored to service starting with the largest and ending with the smallest. 


\section{MAINTENANCE PROGRAM}

Currently, there is no fixed maintenance program for the plant. The chief engineer decides on a daily basis what will get attention. The technical supervisor inspects each machine on his visits and leaves instructions concerning work priority.

Because of the frail condition of most plant components, the operating staff continously tries to make emergency repairs to distribution or production equipment. The condition of the boilers is such that a vast amount of time is spent patching and repairing the tubes, casings, combustion chambers, burners, and controls. Because the two diesel engine generators have been in use only some 25,000 hours, there has been very little maintenance performed on them. The fuel oil systems have required considerable amounts of repair in the past year.

An inspection of the plant in August, 1977 revealed a monumental backlog of needed routine cleaning, insulation repairs, valve and flange steam leak repairs, and building repairs. The installation of proper electrical distribution work has never been completed, and the ancient knife switch model 208-V distribution board with exposed connections is still in place. 


\section{THIS PAGE WAS INTENTIONALLY LEFT BLANK}




\section{FINANCIAL}

Customers of the company's steam service have no boiler rooms, chimneys, or oil storage tanks, so that the alternative to purchasing steam requires a considerable capital investment. Gas fuel is not available in the community, so domestic water heating must be accommodated with either purchased steam, oil heat, or electric heat. Several former customers have disconnected from the steam system and have installed their own boiler room equipment. The cost effectiveness of this option is dependent on the installation expenses that are peculiar to each building.

A comparison of several alternatives for plant customers has been developed to illustrate the situation.

Typical residential customer options:

Case $l$ Steam and electricity purchased from Lawrence Park Heat, Light and Power Co.

Annual present electrical use - $2815 \mathrm{kWh}, 1976$ cost \$ 267.00 Annual present steam use $-85 \mathrm{Kals}, 1976$ cost 816.00 Annual Energy Cost $\$ 1,083.00$

Case 2 Electricity purchased from Con Edison and heat from a new oil-fueled boiler unit.

Electrical cost, 1977 prices Heating costs - fuel 900 gal @ $\$ .48$

$\$ 271.98$

Boiler service and maintenance 432.00

System amortization based on investment of $\$ 1500$ 90.00

Annual Energy Cost $\$ 943.98$

Case 3 A11 electric system, energy purchased from Con Edison.

Electric use, including heat - 27,720 kWh, 1977 cost $\$ 2,267.50$ System investment amortization

Annual Energy Cost More Than $\$ 2,267.50$

The Case 2 alternative to Case 1 is a serious problem to the company because the larger apartment buildings could finance and operate their own boiler plants. Individual, single-family dwellings and duplexes are much more expensive to convert because of space problems and the operating responsibility. If several of the larger apartment customers or the hospital were to install their own heating plants, there would be a major negative impact on the company. 
Cash flow information on the company is available in annual reports to the Public Service Commission. Table 9.1 lists some significant figures for several years showing the effectiveness of Energy Unlimited's management.

TABLE 9.1 LAWRENCE PARK HEAT, LIGHT AND POWER CO. CASH FLOW, 1972 -- 1975

\begin{tabular}{|l|r|r|r|r|}
\hline & 1972 & 1973 & \multicolumn{1}{|c|}{1974} & \multicolumn{1}{|c|}{1975} \\
\hline Operating Revenues & 480,426 & 626,030 & $1,225,862$ & $1,383,408$ \\
Fuel Expenses & 412,942 & 905,811 & 778,621 & 725,063 \\
Operating Income & 67,484 & $(279,781)$ & 447,241 & 658,345 \\
Other Income & 311 & 15,045 & 0 & 0 \\
Depreciation \& Amortization & 35,047 & 39,674 & 91,095 & 102,112 \\
Operating Expenses & 210,953 & Included & 268,371 & 282,240 \\
Gen. Administration Expenses & 180,267 & in Fuel & 119,405 & 146,634 \\
Interest Expense & 36,845 & Expense & 129,485 & 106,979 \\
Net Income (Loss) & $(395,317)$ & $(304,410)$ & $(161,115)$ & 20,380 \\
\hline
\end{tabular}

Financing the major renovations in the plant was difficult for the parent company and required expensive borrowing. The following information in Table 9.2 was obtained from the annual reports of Energy Unlimited, Ltd.

TABLE 9.2 ENERGY UNLIMITED AND SUBSIDIARY, CONSOLIDATED STATEMENT

\begin{tabular}{|l|c|r|r|}
\hline & 1973 & \multicolumn{1}{|c|}{1974} & \multicolumn{1}{|c|}{1975} \\
\hline Operating Revenues & $\$ 891,653$ & $\$ 3,446,358$ & $\$ 4,721,570$ \\
Operating Expenses & 440,511 & $3,052,045$ & $4,112,535$ \\
Depreciation \& Amortization & 122,621 & 196,214 & 270,974 \\
Operating Income & 328,521 & 198,099 & 338,061 \\
Other Income & $(80,638)$ & 205,452 & 103,944 \\
Income Deductions & 416,369 & 344,814 & 340,663 \\
\hline Net Income & $(\$ 168,486)$ & $\$ 58,737$ & $\$ 101,342$ \\
Net Income/Common Share & $(\$ .52)$ & $\$ .19$ & $\$ .30$ \\
\hline
\end{tabular}




\section{REGULATORY CONTROL}

A major decision to operate a regulated utility was made by Energy Unlimited when the opportunity to gain control of Lawrence Park Heat, Light and Power Co. was offered. The parent company is unregulated and provides management and administrative services to the utility company. Costs for these services were scrutinized by the Public Service Commission and were adjusted downward in the most recent rate application.

Regulation authorities require annual reports describing the present status of plant property, production figures, fuel-use figures, description of construction work in progress, revenue and sales data for various classes of customers, and itemized operating cost information. Data for the reports are provided from daily and monthly plant operating records and from sales and expense ledgers. The reports carefully separate revenue, expenses, and plant investment into Steam Utilities and Electric Utilities.

An application to change rates charged the plant customers requires extensive documentation, analysis by the PSC examiners, and public hearings in the community. The application for rate change must present evidence of need -- comparison of the rate of return experienced under current rates with the anticipated return if the increase were granted and justification for the change.

At the time Energy Unlimited chose to go into the regulated utility business, it was reasoned that the regulators had a duty to protect the utility as wel1 as the customer. This quotation from the 1974 PSC Examiner's report justifies that decision:

In order for LPCO to eam an $8.45 \%$ rate of return found to be reasonable on its electric operations, LPCO requires annual electric revenues of $\$ 274,289$ for an increase of $\$ 50,850$ in annual electric revenues . . . .

In order for LPCO to ear a $22.26 \%$ rate of return found to be reasonable on its steam operations, LPCO requires annual steam revenues of $\$ Z, Z 38,320$ for an increase of $\$ 2 Z 3,600$ in connual steam revenues ....

One of the liabilities of regulated utility status is the firm obligation to provide service upon request to established customer premises. At Lawrence Park Heat, Light and Power Co., one of the oldest low-pressure steam distribution mains runs over $1000 \mathrm{ft}$ up and down hill to serve a few dwelling units. The 
piping is in poor condition, and the costs of repair or replacement could never be recovered from steam sales revenue in the area served. Although the utility company loses money on this portion of its service area, it is nonetheless, obliged to continue service to the customers. An informal inquiry by the company to the PSC has been made to obtain an opinion on the proposal to terminate steam service in this area. Under this proposal, the company would furnish, install, operate, and maintain small, oil-fired heating boilers at each building and would make connections to the existing building steam heating systems. The tenants then would be charged for the costs of steam as determined by the amount of fuel burned in the local boiler. After a period of about five years, during which the company should have received its new investment, the boilers would be sold to the property owners for $\$ 1.00$, and the utility would no longer have a responsibility to serve the site. This matter is presently being investigated by the PSC.

Consolidated Edison surrounds the Lawrence Park Heat, Light and Power Co. territory and can provide electric service to most of the local utility company tenants with little investment. Con Edison refuses to allow any of its present customers to buy power from Lawrence Park Heat, Light and Power Co. This restriction is part of the exclusive franchise concept that is fundamental to regulated public utilities. 


\section{PERFORMANCE EVALUATION}

The extensive changes in the power generation system made in 1973-1974 have produced economics of operation as predicted. Shutdown of the steam turbines and use of heat recovery from diesel engine generators have reduced the fuel consumption remarkably as shown in Table 5.1.

Steam system improvements including a new, efficient boiler, deaerating feedwater heater, improved chemical treatment of makeup water, electric-drive feed pumps, and vastly improved burner adjustment have made additional reductions in operating costs and have improved dependability.

The influence of electric generation system changes are identified in the following comparison:

$$
\begin{aligned}
& 1972 \text { - Fuel Used } \quad=3,572,162 \text { gal } \\
& \text { Steam Sold }=134,326 \mathrm{Kals} \\
& \text { Electricity Sold }=3,461,089 \mathrm{kWh} \\
& 1974 \text { - Fuel Used } \quad=2,287,128 \mathrm{gal} \\
& \text { Steam Sold }=135,060 \mathrm{Kals} \\
& \text { Electricity Sold }=2,900,843 \mathrm{kWh} \\
& \text { If the electricity sales had been } 560,000 \\
& \text { kWh more (to equal 1972) the plant would } \\
& \text { have used an additional 55,088 gal of oil. } \\
& \text { Apparent reduction in } 0 i 1 \text { use for equival- } \\
& \text { ent production, 3,572,162 ga } 1 \text { minus 2,955, } \\
& 931=616,230 \text { gal } \text {. }
\end{aligned}
$$

Energy Unlimited took over a poorly performing plant and has transformed it into a satisfactory utility service. The 1974 PSC Examiner's Report clearly states that in 1972, there was a substantial degree of customer dissatisfaction with the quality of service provided by the company. As of 1974, the company had demonstrated that it is making substantial progress effectively to remove its service deficiencies... all of them (customers who complained about power failures and noise) complimented the present management of LPCO for its extensive and energetic efforts to restore the physical plant of the company and to elevate the level of utility service being rendered.

As a profit-making business, the company has not been a success. The revenues have increased greatly in the past four years, but so have the expenses. The cash flow information tabulated in Table 9.1 shows that annual losses sustained in 1973 and 1974 have been, respectively, $\$ 304,000$ and $\$ 161,000$. In 1975, the 
last year for which reports are available, the available revenue covered al1 outof-pocket costs, and a $\$ 20,380$ profit resulted after allowing $\$ 102,112$ for depreciation and amortization. Considering only the initial $\$ 700,000$, the plant rehabilitation investment made by Energy Unlimited, the venture has not been rewarding.

Moreover, as an energy conversion system, the power plant and its delivery system are only moderately efficient. The following energy use effectiveness calculations are all developed on the basis of delivering the same product to the customers.

Lawrence Park Heat, Light and Power Co. as now operated is a reasonably efficient power producer, but operates at less than $50 \%$ annual efficiency as a heating plant. This may be the result of poor customer metering, excessive losses in the distribution system and inefficient boiler operation under peak load conditions. The products referred to in Fig. 11.1 are net sales to customers.

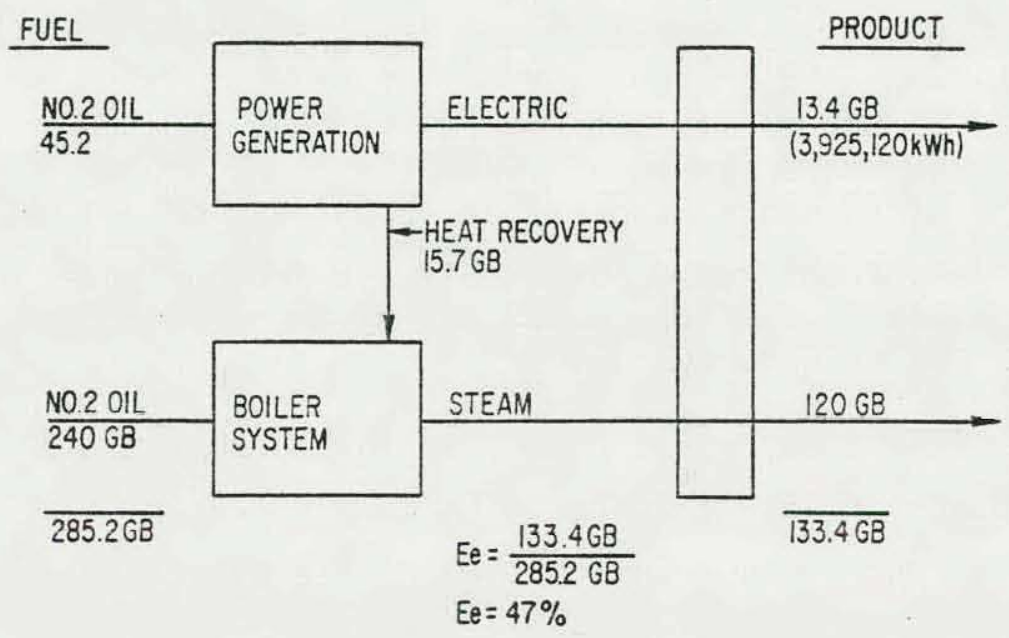

Fig. 11.1: 1976 Current Operating Mode

Case 2 (Fig. 11.2) is a possible alternative method of serving the community energy needs by purchasing a11 electricity from Con Ed and equipping each steam customer with an oil-fired boiler. Note that the assumed annual boiler efficiency is $60 \%$, and this may be overly optimistic, considering that the boiler would operate intermittently at very light loads to serve domestic hot water needs much of the time. Some of the larger buildings could achieve better performance than indicated. The power generation fuel is estimated to be less than in Case 1 (Fig. 11.1), but none of the fuel energy is recovered for Con Ed. 


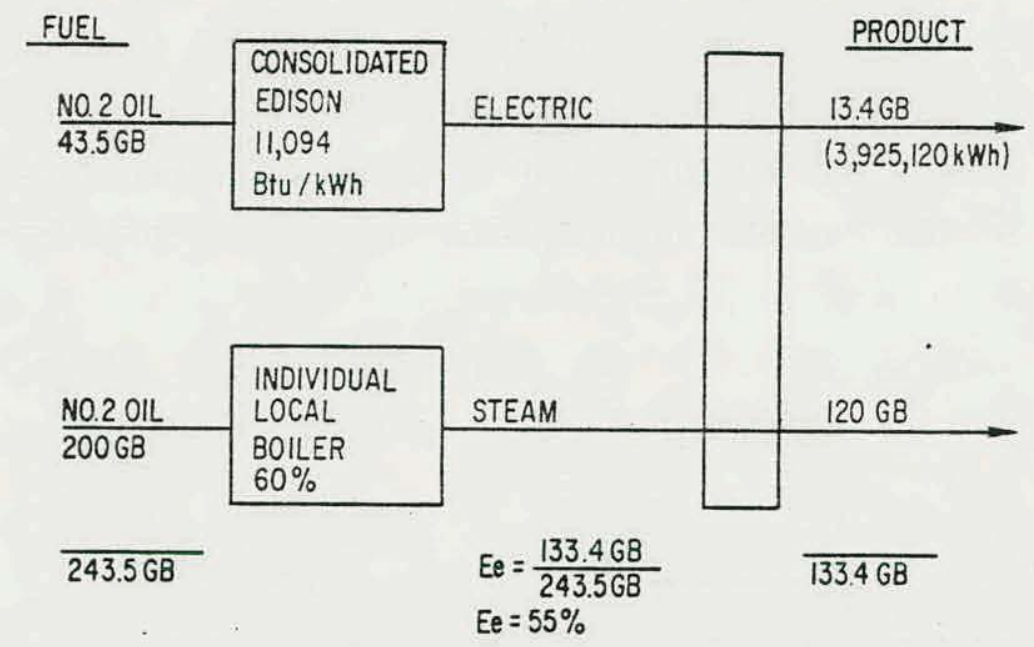

Fig. 11.2: Purchased Power - Local Individual Boilers

Another possible energy delivery system would be the conversion of all the heating loads to electric heat, except the hospital which would be equipped with boilers under Case 3 (Fig. 11.3). The vast increase in fuel needed for power generation at Con Ed would reduce the energy use effectiveness because none of the waste heat could be recovered from their plants.

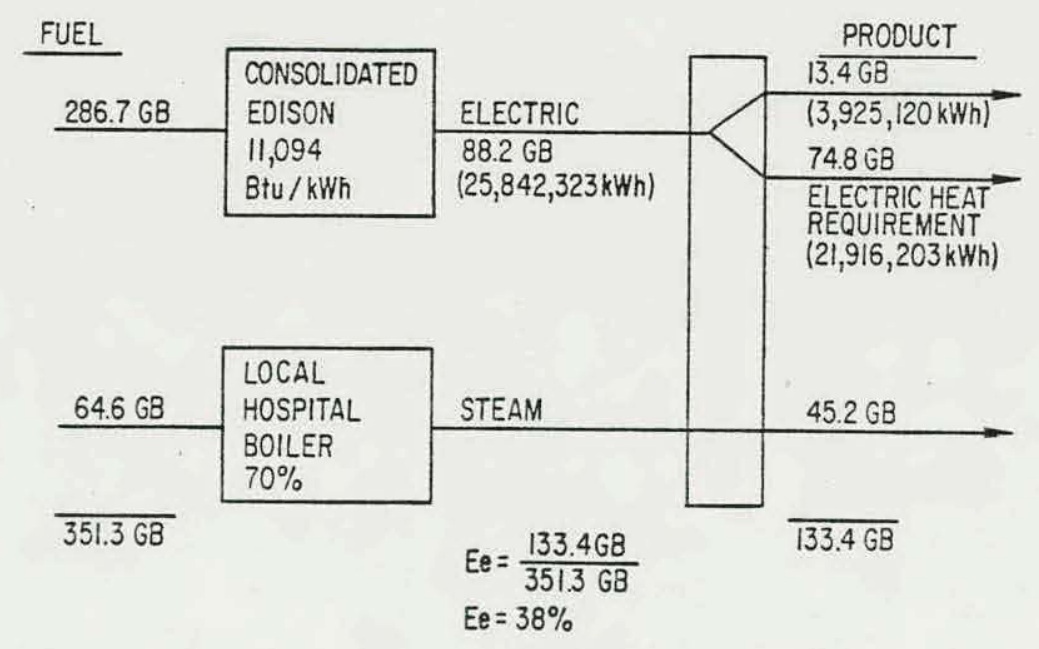

Fig. 11.3: A11 Purchased Power -- A11 Electric Heat Except Lawrence Hospital 
Case 4 (Fig. 11.4) contemplates shutting down the Lawrence Park Heat, Light and Power Co.: electric system and transferring a 11 the electric loads to Con Ed. The steam plant would remain in service and continue to operate in the same manner as now, except that the heat now gained by recovery from electric generation would have to be obtained from the boilers. This scheme achieves a reasonably good energy effectiveness even though the boiler plant and delivery system are less than $50 \%$ efficient.

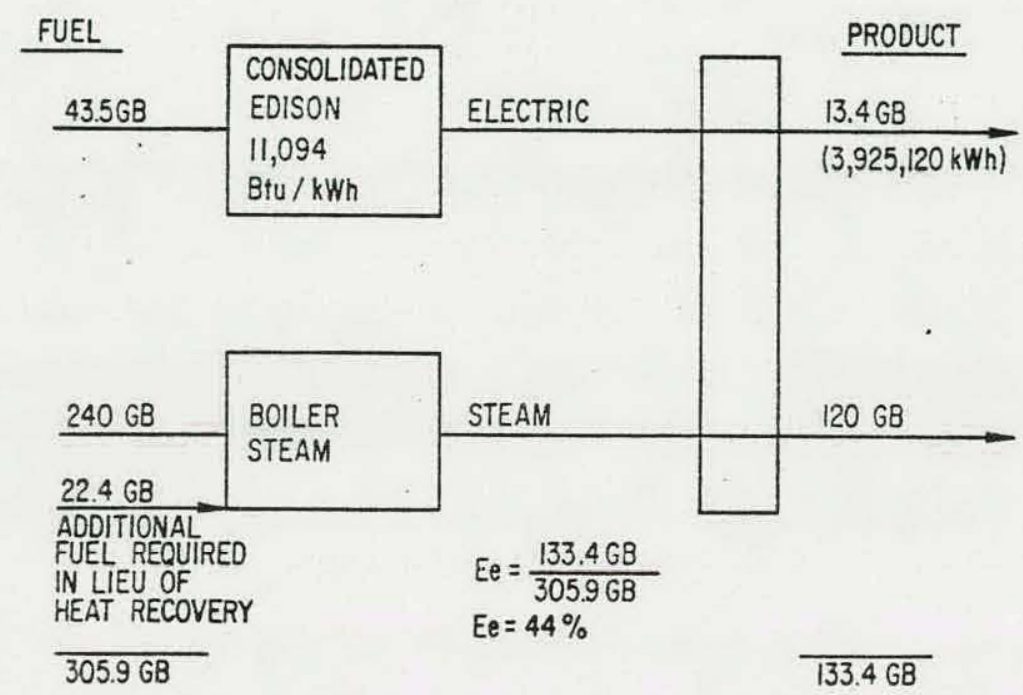

Fig. 11.4: Steam Heating Plant -- Purchased Power 


\section{ALTERNATIVES}

Economic viability is the most pressing need for Lawrence Park Heat, Light and Power co. Further steam steam service rate increases may cause further shrinkage of the load and revenue. Increases in electric rates above Con Ed's rates would also drive the customers away. The management sees its future opportunity in load growth. If there were new buildings developed in Lawrence Park's franchise area, the load would increase revenues and investment expense might be minima1. In 1973, the hope was that a replacement for the Gramatan Hotel load would surely develop on that site. Capacity exists in the plant and distribution equipment to serve a concentrated load at the old hotel location. Other smaller properties in the area might be replaced with larger facilities that would increase the loads. The plant could supply $50 \%$ more energy with the same staff. With new loads committed to the plant, further investment in improved facilities might be warranted, and the efficiencies could be improved resulting in lower unit costs to everyone.

Disposition of the uneconomic, remote, small steam and electric customers would improve the company profit potential. Some way must be found to terminate such service, or the loads must be increased to utilize the new investment that is necessary to serve the area properly.

Annual reports to the Public Service Commission show a loss for the electric side of the business. In 1975, the company showed a loss of $\$ 111,334$ on the electric business that has a total revenue of $\$ 260,853$. In the same year, the steam sales of $\$ 1,122,555$ yielded a profit of $\$ 123,813$. If there is no load growth to increase the business opportunity of the electric system, the company would do well to let Con Ed have the electric customers.

One way of increasing electric revenues would be to sell peaking power to Con Ed and recover and use the heat from power it produces for Con Ed. In periods when neither utility has much load and the larger generating system is using only highiy efficient baseload plants, it would be helpful to shut down Lawrence Park Heat, Light and Power Co. generation and buy power, or trade it. The off period would be useful for service and maintenance purposes, and there should be no increace in energy costs compared with onsite generation.

The area of Bronxville served by this plant has retained its value as a residential and commercial neighborhood. The power plant property was allowed 
to disintegrate for a period, and it lost its place in the community. As new development occurs in Bronxville, the power plant must expand to retain its economic viability. Recent decision of the hospital to continue to rely on Lawrence Park Heat, Light and Power Co. for all its steam including a sizable increase in use gives the plant a boost. Two or three more good load additions would bring the opportunity to the company that could justify the investments already made. 


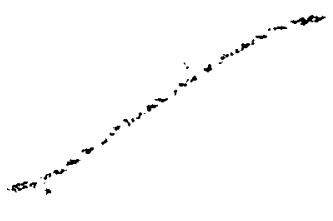

$\begin{array}{lll}3 & \\ \vdots & & \\ \vdots & & \\ \vdots & \cdots & \cdots\end{array}$

-

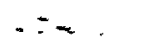

